itself expects to lose money on 80 percent of the books it publishes; the problem occurs in recognizing which 80 percent. ${ }^{10} \mathrm{Fi}$ nally, no one doubts that undergraduates don't read Choice. But as Evan Farber has pointed out, perhaps it is our responsibility to further educate library users in the value of knowing "how to select books before reading them, not just how to use the card catalog."

\title{
REFERENCES
}

1. The Idler, no.86 (1 Dec. 1759).

2. Choice, 1:13-15 (Mar. 1964).

3. Ibid.

4. Beth Macleod, "Library Journal and Choice: A Review of Reviews," Journal of Academic Librarianship, 7:23-28 (Mar. 1981).

5. Daniel Ream, "An Evaluation of Four Book Review Journals," $R Q, 19: 149-53$ (Winter 1979).

6. Bowker Annual of Library and Book Trade Information. (26th ed.; New York: Bowker, 1981), p.328, p.355.

7. Richard Hume Werking and Charles M. Getchell, Jr., "Using Choice as a Mechanism for Allocating Book Funds in an Academic Library," College and Research Libraries, 42:134-38 (Mar. 1981).

8. Allen Kent, and others, Use of Library Materials: The University of Pittsburgh Study. (New York: Dekker, 1979), p.10.

9. Beth Macleod, "Library Journal and Choice: A Review of Reviews," p.27.

10. New York Times, (15 Jan. 1982), sec. 3, p.22.

11. American Libraries, 7:515 (Sept. 1976).

\section{A Methodology for Estimating the Size of Subject Collections, Using African Studies as an Example}

\section{Joseph J. Lauer}

This note provides a formula for estimating the number of Africana titles in large libraries using the Library of Congress classification schedule. The methods used to establish this formula could be used for other subjects, and an analysis of the completeness of LC class numbers for a given subject would seem to be an essential first step in developing a useful conspectus or in compiling a questionnaire on subject strengths.

Shelflist measurement has become a fairly common method of determining the number of titles held in broad subject cate- gories. But most subjects are scattered to some extent, and this problem is especially severe with area studies. For example, books about Africa are found throughout the LC schedule, with a concentration in the DT section. Thus, before one can make an objective estimate of the total number of Africana titles, it is necessary to establish what percent of all cataloged Africana falls in the DT section (which is exclusively Africana).

There are at least two ways to determine the percentage of all Africana falling in the DT section: (1) describe and analyze the 
distribution of titles in a library with a separate shelflist; or (2) do the same for a library with a "comprehensive" and detailed conspectus of holdings on a subject. The first method is used here because separate Africana shelflists do exist at Michigan State University (MSU) and at Indiana University-Bloomington (IU). Furthermore, the author does not know of any complete list of Africana call numbers, and he doubts that any conspectus for area studies would locate more than 95 percent of the classified titles.

The supplementary shelflists for Africana books in the MSU and IU libraries were measured in 1980 by the author (at MSU) and by Bill Rafferty under the supervision of David Easterbrook (at IU). All data was reported in percentages rather than inches or centimeters, and no attempt was made to convert titles into volumes. Both the distribution of multicard sets for single titles and measuring errors are assumed to be random. In addition to uncataloged titles, which are not represented in either shelflist (nor in these libraries' reports to the Joint Acquisitions List of Africana), the measurements also excluded microforms and government documents not classified according to the LC schedule.

Table 1 demonstrates that Africana titles appear in each of the large LC classes, in a distribution pattern that is surprisingly similar to that for all titles at the Library of Congress. But what is needed are percentages for the sections of the LC classification that are exclusively Africana. A comprehensive list would include hundreds of categories, but Boston University's African Studies Library did identify 20 sections which they now shelve separately in their African alcove. Using these 20 as a start, those covering less than one percent of the Africana at MSU and IU were dropped and others covering at least one percent were added. ${ }^{\star}$ Table 2 presents the percentages for eleven core categories, which accounted for approximately 57 percent of the total in the separate shelflists.

In addition to the raw data for a formula, table 2 lists information on the comprehensiveness of the two specialized shelflists.t As expected, omissions were not randomly distributed. The DT section was generally more complete, while the MSU Africana shelflist was poor in its coverage of literature, and the IU African Studies shelflist lacked many of the materials purchased on Near East funds. After adding the extra titles from the main shelflist, and assuming that the Africana for categories not listed in table 2 are omitted at the same rate as the non-DT categories in table 2, one finds 34.5-36.5 percent of Africana falls in DT, 19.5-21.1 percent falls in the other 10 listed in table 2, and 42.4-46.0 percent falls outside these call numbers.

Therefore, one can multiply the titles in DT by 2.8 to estimate the number of classified Africana titles. Multiplying the results of the top eleven categories by 1.8 would give similar, but not necessarily more accurate, results. Figures for the non-DT categories are more useful as a test of particular Africana strengths or of the representativeness of the DT results.

A major problen with this formula is that the DT section includes Egyptology and other titles about Northern Africa which are usually excluded from the de facto (but not formal) definition of African Studies. Thus, if one measures only the DT section, libraries supporting strong Near East programs will register as strong in African Studies even if they were relatively weak for Sub-Saharan Africa. The absence of a separate shelflist for Africana without Northern Africa complicates the resolution of this problem.

Table 3 presents figures on the relative

\footnotetext{
${ }^{*} \mathrm{KT}$, which accounted for 2.1 percent of MSU's Africana shelflist, was dropped from the final list because it did not appear in the IU list and law materials are often not reported in the main shelflist. If one was serious about including materials about North Africa, the appropriate call numbers from PJ should be added. Other candidates for inclusion include BL2400-2490, GR350-360, HA1951-2227 (especially if volumes rather than titles were counted), and HD2117-2151.

tNo attempt was made to estimate the number of relatively rare titles that really did not belong in an Africana shelflist.
} 
TABLE 1

DISTRIBUTION OF TITLES

\begin{tabular}{|c|c|c|c|}
\hline $\begin{array}{l}\text { LC } \\
\text { Call } \\
\text { Nos. }\end{array}$ & $\begin{array}{l}\text { MSU Africana } \\
\text { Sheiflist } \\
1980(\%)\end{array}$ & $\begin{array}{c}\text { IU African } \\
\text { Studies } \\
\text { Shelflist } \\
1980(\%) \\
\end{array}$ & $\begin{array}{c}\text { All Titles } \\
\text { LC Shelflist } \\
\text { on Microfiche } \\
1981(\%) \\
\end{array}$ \\
\hline A & 0.4 & 0.3 & 1 \\
\hline B & 3.7 & 4.5 & 7 \\
\hline C & 0.4 & 0.4 & 1 \\
\hline D & 38.3 & 39.3 & 9 \\
\hline E-F & 0.4 & 0.9 & 4 \\
\hline G & 4.4 & 6.9 & 4 \\
\hline $\mathrm{H}$ & 18.3 & 13.9 & 13 \\
\hline $\mathrm{J}$ & 4.0 & 4.2 & 3 \\
\hline K & 2.3 & 0.5 & 2 \\
\hline $\mathrm{L}$ & 2.8 & 2.0 & 3 \\
\hline M & 0.3 & 0.5 & 7 \\
\hline $\mathrm{N}$ & 1.6 & 2.1 & 3 \\
\hline $\mathrm{P}$ & 10.3 & 16.0 & 20 \\
\hline Q & 3.9 & 2.0 & 7 \\
\hline $\mathrm{R}$ & 1.0 & 0.6 & 3 \\
\hline & 3.6 & 1.0 & 2 \\
\hline $\mathrm{T}$ & 1.1 & 0.7 & 7 \\
\hline U-V & 0.2 & 0.2 & 1 \\
\hline$Z$ & 3.1 & 3.8 & 3 \\
\hline
\end{tabular}

TABLE 2

CORE CATEGORIES OF AFRICANA

\begin{tabular}{|c|c|c|c|c|c|}
\hline Call Nos. & MSU & $\begin{array}{c}\text { Percentage of } \\
\text { Africana/African } \\
\text { Studies Shelflists } \\
\end{array}$ & MSU & $\begin{array}{l}\text { Main Shelflist } \\
\text { as a Percent of } \\
\text { Special Shelflist }\end{array}$ & IU \\
\hline BV3500-3630 & 1.6 & 1.4 & 104 & & 104 \\
\hline DT & 36.5 & 37.7 & 101 & & 113 \\
\hline GN643-661 & 1.1 & 1.6 & 108 & & 100 \\
\hline HC501-599 & 4.6 & 3.0 & 109 & & 130 \\
\hline HN771-840 & 0.9 & 1.0 & 104 & & 143 \\
\hline JQ1870-3981 & 1.9 & 1.7 & 104 & & 163 \\
\hline LA $1500-2090$ & 1.0 & 0.9 & 108 & & 121 \\
\hline PL8000-8844 & 3.8 & 5.9 & 106 & & 106 \\
\hline PQ3980-9 & 1.2 & 1.7 & 126 & & 115 \\
\hline PR9340-9408 & 1.3 & 1.7 & 150 & & 126 \\
\hline Z3501-3975 & 1.5 & 1.8 & 107 & & 104 \\
\hline Total & 55.4 & 58.4 & & & \\
\hline
\end{tabular}

TABLE 3

DISTRIBUTION OF TITLES ABOUT NORTHERN AFRICA

\begin{tabular}{|c|c|c|c|c|c|}
\hline \multirow[b]{2}{*}{$\stackrel{\text { A }}{\text { Africana Call Nos. }}$} & \multirow[b]{2}{*}{$\begin{array}{c}\text { B } \\
\text { North Africana Call Nos. }\end{array}$} & \multicolumn{4}{|c|}{ cent of $\mathrm{A}$} \\
\hline & & $\begin{array}{l}\text { Africana } \\
\text { Shelflist }\end{array}$ & $\begin{array}{l}\text { Main } \\
\text { Shelflist }\end{array}$ & $\begin{array}{l}\text { IU } \\
\text { African Studies } \\
\text { Shelflist }\end{array}$ & $\begin{array}{l}\text { Main } \\
\text { Shelflist }\end{array}$ \\
\hline BV3500-3630 & BV3570-3605 & 0.1 & 0.1 & 0.7 & 2.1 \\
\hline DT & $\begin{array}{l}\text { DT } 43-107,137-154 \& \\
\quad 160-346\end{array}$ & 12.5 & 13.7 & 17.1 & 24.6 \\
\hline GN643-661 & GN649 & 2.8 & 2.6 & 1.2 & 2.0 \\
\hline HC501-599 & $\begin{array}{l}\text { HC531-540, 547.A4 \& . T8, } \\
\text { 567.L5 \& 591.M8 }\end{array}$ & 4.3 & 5.4 & 8.3 & 17.3 \\
\hline HN771-840 & HN782-6 & 1.6 & 3.0 & 0 & 19.3 \\
\hline JQ1870-3981 & $\begin{array}{l}\text { JQ3189, 3200-3339, } \\
3590-9,3800-99,3940-9\end{array}$ & 3.5 & 4.8 & 7.8 & 34.6 \\
\hline LA1500-2090 & LA1645-9, 1670-4, 1940-4 & 4.0 & 3.7 & 1.1 & 18.0 \\
\hline PL8000-8844 & & 一 & - & - & - \\
\hline PQ3980-9 & & - & - & - & - \\
\hline PR9340-9408 & & - & - & - & - \\
\hline Z3501-3975 & $\begin{array}{l}\text { Z3651-9, 3681-5, 3836-40, } \\
3933 \text { \& } 3971\end{array}$ & 3.8 & 4.1 & 5.0 & 7.4 \\
\hline
\end{tabular}


size of the subsections on Northern Africa. * Since the DT section contains a significantly greater proportion of titles on Northern Africa, the formula given above must be adjusted. An analysis of the numbers in tables 2 and 3 reveals that for Africa without Northern Africa, the DT section of the main shelflist contains 59-61 per- cent of the total for the core eleven categoriest or 32.4 percent of the total for all classifications at MSU, and 34.0 percent at IU. This is close enough to 33.3 percent to make 3.0 an accurate multiplier of DT without Northern Africa to estimate titles on Sub-Saharan Africa.

*The Sudan is considered part of Sub-Saharan Africa in this paper. Books about Africa as a whole are also included with Sub-Saharan Africa.

tMeasuring the main shelflist at UCLA in 1983 revealed that DT was 66 percent of the total for the core eleven categories but 61 percent for the same categories after titles on Northern Africa were excluded.

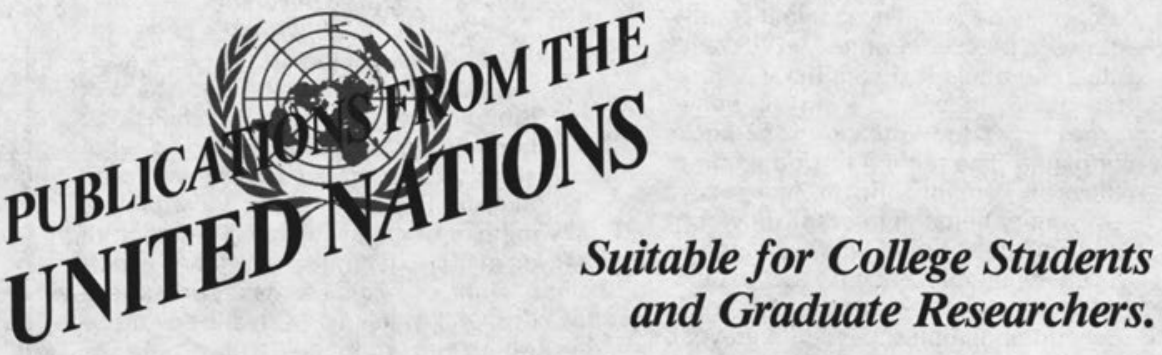

\section{WORLD ECONOMIC SURVEY 1983}

Provides an appraisal of current trends in the world economy, their effects on development and the requirements for international cooperation. Chapter I presents the current outlook, analyses the adjustment to world recession taking place in developing countries and discusses policies for a sustained world recovery. Chapter II traces main developments and issues affecting international trade and payments. Chapter III reviews the main dimensions of the global recession and short term growth prospects. 


\title{
The Adventures of TODM SAW W
}

\author{
by MARK TWAIN \\ A facsimile of the author's holograph manuscript
}

This facsimile edition of Mark Twain's handwritten manuscript of The Adventures of Tom Sawyer offers to both the specialist and the general reader the sense of looking over the shoulder of America's favorite writer and coming as close as will ever be possible to witnessing the creation of a literary masterpiece. From original notes and composition through final revision, we can now see Tom Sawyer taking shape in Mark Twain's clear and precise handwriting. In both its literary significance and its handsome presentation, this large two-volume work is one of the year's major publishing events. The manuscript has been reproduced in a limited edition of 1,000 sets. Included with the facsimile is an introduction by Professor Paul Baender, who recently edited the definitive printed edition of Tom Sawyer. The facsimile edition has been published by University Publications of America and the Georgetown University Library.

Collectors will prize these two handsome volumes, and scholars and teachers will use them. The facsimile reproduces in black and white Mark Twain's clear, readable text with his revisions, marginal notes, and even his sometimes unrelated jottings on the backs of pages. The faithful reproduction of the original manuscript at Georgetown University belongs in other university and college libraries, where it will serve as an invaluable teaching tool to demonstrate Mark Twain's steady, confident composition and the often revealing changes he made in his text.

The 28-page introduction by Paul Baender (textual editor of the lowaCalifornia edition of Tom Sawyer) relates this Georgetown manuscript to the scribal copy in Missouri and to the printed Tom Sawyer. Taken with Baender's illuminating portrait of Mark Twain's creative process, the facsimile text gives the student a rare opportunity to see a classic of our literature as it grew under the author's hand.

- Thomas A. Tenney

Editor, Mark Twaln Journal
The manuscript brings pleasant shocks of recognition, and the effect is heightened because you can see where Mark Twain tinkered to tighten a paragraph or bring off a scene. The changes add to the tone of the book, enriching its texture, sharpening its humor, enhancing its perfect, dusty sense of reality.

\section{-Phil McCombs The Washington Post}

These two volumes are more fun than Pac-Man. We can watch a book being shaped, reshaped, and triumphantly finished. It doesn't hurt-in fact it helps the suspense of the scholarly and critical user-to know that the result is going to be an American and, indeed, a world masterpiece. Everyone can get a sharpened awareness from this beautifully readable, "live" manuscript.

\section{-Louis J. Budd \\ Professor and Past Chairman Department of English Duke University}

It's wonderful looking over the master's shoulder, watching him sharpen the picture, softening harshness or harshening softness, stretching what starts out as a four-foot fence into a nine-foot fence, making a cat prance instead of caper (which it had tried to do at first), getting an intonation exactly right.... This seems a perfect replica of Twain's work. It's a delight to watch him work.

\section{-George Christian \\ The Houston Chronicle}

List Price: $\$ 120$

(two large hardcover volumes, boxed). Available now.

Kindly direct all orders and inquiries to:

UNIVERSITY PUBLICATIONS OF AMERICA 44 North Market Street • Frederick, MD 21701 (301) 694-0100 